\title{
Ulcerative colitis: one disease or two? (Quantitative histological differences between distal and extensive disease)
}

\author{
D Jenkins, A Goodall, B B Scott
}

\begin{abstract}
Cell counts and measurements of mucosal architecture were made on rectal biopsies from nine patients with total colitis, eight with left sided colitis, 15 with distal colitis, and 11 with proctitis. The mean total lamina propria cell count in proctitis and distal colitis approached twice that of extensive left sided and total colitis $(\mathbf{p}<0.001)$ and in distal proctocolitis the cell numbers are further increased in the chronic over the acute phase. This difference was not explained by age, duration, activity, or treatment. The predominantly increased lymphoid and mononuclear cell infiltrate in distal proctocolitis indicates a different pattern of immune response, suggesting a separate process from extensive colitis or a more intense reaction resulting in localisation of disease.
\end{abstract}

Ulcerative colitis may involve varying lengths of large bowel extending from the rectum. The term idiopathic, or non-specific, proctitis is applied to patients with inflamed rectal mucosa which has an upper limit in the rectum.' Similar changes extending into the sigmoid colon are termed proctosigmoiditis or distal proctocolitis. $^{23}$ Although a proportion of cases with distal disease on barium enema will have more extensive disease on colonoscopy and biopsy, ${ }^{45}$ and it is still unclear whether the general view that all are manifestations of one disease is correct. $^{1-9}$ The gross and microscopic appearances and the medical treatment of localised and extensive colitis are similar ${ }^{169}$ although a small group of cases of 'follicular proctitis' with prominent lymphoid follicles, ${ }^{10}$ and a group of young children with allergic proctitis characterised by large numbers of eosinophils ${ }^{11}$ have been proposed as distinct diseases. Suggestions of an $\operatorname{IgE}$ mediated basis for other cases of proctitis have not been confirmed. ${ }^{12} 13$

Although limited extension of proctitis or distal colitis has been reported in $4-45 \%$ of cases, only $10-15 \%$ extend to the proximal colon. ${ }^{3+6-9}$ There is also only a very low risk of malignancy or systemic complications developing in distal colitis. $^{389}$ It is therefore entirely possible that those patients with disease which remains localised are a separate group with a different pathogenesis.

We have previously shown the ability of histological measurements of cell populations and mucosal architecture to identify otherwise undetectable minor changes of inflammatory bowel disease, and to distinguish inflammatory bowel disease from infective colitis. ${ }^{1+15}$ Quantita- tive histological rectal mucosal biopsy changes in carefully matched groups of patients with proctitis and distal colitis were therefore compared with the changes in extensive ulcerative colitis.

\section{Methods}

SUBJECTS

The disease group of 43 patients were all primary referrals to one district general hospital with sigmoidoscopic and biopsy appearances typical of active ulcerative proctocolitis. In none was there evidence of Crohn's disease. All cases were characterised clinically as acutely active, either at onset or exacerbation, or as chronic but still active at the time of the biopsy. Acutely active cases were defined as those with recent (within 12 weeks) onset of diarrhoea either at first onset of disease or during an exacerbation, with endoscopic evidence of inflammation. Chronic activity was defined as symptoms persisting more than 12 weeks, and all had endoscopic abnormality of the mucosa. Patients in complete clinical and endoscopic remission were excluded. The patients were initially divided into four groups on the basis of extent of disease defined by either double contrast barium enema and sigmoidoscopy or by colonoscopy performed at or about the same time as the rectal biopsy examined. Rectal biopsies were taken during the course of routine management.

\section{TOTAL COLITITIS}

Nine patients, seven men, five acute, with continuous disease extending into the right side of the colon, mostly to the caecum. The median age was 43 years (range 16-70), median duration of the current active state - that is, since first onset or ending of the last remission) was two months (range three weeks to eight years), and median total follow up was 11 years (range three to 35). Four were taking sulphasalazine and none were on steroids.

\section{LEFT SIDED COLITIS}

Eight patients, three men, three acute, with continuous disease extending into the descending colon, but not higher than the mid transverse colon. Median age was 35 years (range 19-74), duration one month (range one week to one year), and total follow up nine years (range 3.515). Four were taking sulphasalazine and three were also on steroids.

DISTAL COLITIS

Fifteen patients, seven men, six acute, with
Correspondence to: Dr Jenkins, Department of Histopathology, Whittington Hospital, Highgate
London N19 $\mathrm{NF}$

Accepted for publication 27 June 1989 
continuous disease extending into the sigmoid colon but not into the descending colon. Median age was 35 years (range 19-55), duration seven months (range two weeks to two years), and total follow up nine years (range 3.5-14.5). None of these patients was known to have progressed to more extensive disease during this time as judged by repeat double contrast barium enema or colonoscopy. Six were taking sulphasalazine and three were also on steroids.

\section{PROCTITIS}

Eleven patients, four men, four acute, with continuous disease confined to the rectum. Mean extent was $8.5 \mathrm{~cm}$ and the maximum $15 \mathrm{~cm}$. Median age was 34 years (range 24.75), duration four months (range eight weeks to 2.5 years), and total follow up 12 years (range eight to 20). Only one patient was known to have progressed to left sided colitis on repeat colonoscopy and this patient's biopsy was used only as a test case. Six patients were taking sulphasalazine and three were also on steroids.

The control group comprised 23 patients, nine men, median age 38 years (range 20-73) who had no evidence of organic gastrointestinal disease and were considered to have irritable bowel syndrome.

\section{PROCEDURE}

Rectal biopsies were immediately fixed in formalin. Well oriented biopsies of adequate size were cut at $1 \mu$ thickness perpendicular to the mucosal surface, and sections were stained with haematoxylin and eosin for counts of polymorphs and total cellularity and for architectural measurements. IgA, IgM, and IgG plasma cells were shown using a peroxidase-antiperoxidase technique. Measurements were carried out using a MOPPET image analyser. The method has

TABLE I Variables measured or computed and used in the analyses

\begin{tabular}{ll}
\hline IGM & Plasma cells/mm mucosal length \\
IGG & Plasma cells/mm mucosal length \\
IGA & Plasma cells/mm mucosal length \\
SIE & Surface intraepithelial polymorphs/mm mucosal length \\
CIE & Crypt intraepithelial polymorphs/10 crypts \\
CLUM & Crypt lumen polymorphs/10 crypt lumens \\
LPP & Lamina propria polymorphs/mm mucosal length \\
CELLEN & Total lamina propria cells/mm mucosal length \\
CARE & Total lamina propria cells/mm' mucosa \\
HCDENS1,2,3 & Total cell densities in superficial, middle and basal bands of lamina propria \\
HCDRAT & respectively \\
& Ratio of total cell density in superficial horizontal band of lamina propria to that in \\
SLR & basal band \\
MLA & Measured surface length: smoothed surface length \\
CAMM & Lamina propria area/mm mucosal length \\
CRYPTS & Total crypt area/mm mucosal length \\
CRYPTEQV & Number of crypts/mm surface length \\
CRYVOLI & Pumber of crypt profiles/mm mucosal length, weighted by length \\
& Percentage of a line, superimposed on the mucosa one-third down from the surface, \\
CRYVOL2 & occupied by crypt \\
& Percentage of a line, superimposed on the mucosa two-thirds down from the \\
CRYVOLT & surface, occupied by crypt \\
MHMEAN & Percentage of whole mucosa occupied by crypt \\
CLMEAN & Mean of mucosal height measurements \\
CDMEAN & Mean of crypt length measurements \\
SEWMEAN & Mean of mucosal diameter measurements \\
CEWMEAN & Mean of surface epithelial width measurements \\
ICDMEAN & Mean of crypt epithelial width measurements \\
MHCOEFF & SDMH/MHMErcrypt distance measurements \\
CLCOEFF & SDCL/CLMEAN \\
CDCOEFF & SDCD/CDMEAN \\
SEWCOEFF & SDSEW/SEWMEAN \\
CEWCOEFF & SDCEW/CEMEAN \\
ICDCOEFF & SDICD/ICDMEAN \\
MUCLRAT & MHMEAN/CLMEAN \\
SCHEWRAT & SEWMEAN/CEWMEAN \\
\hline
\end{tabular}

$\mathrm{SD}=$ Standard deviation. been described previously; ${ }^{1+}$ the variables are shown in Table I.

\section{STATISTICAL ANALYSIS}

Variables were transformed where necessary to normalise the distribution. The Mann-Whitney $\mathrm{U}$ test was used to compare age and duration of disease, and $\chi^{2}$ numbers on drug treatment, with colonoscopy and with acute and chronic disease in each group.

All other analyses were carried out using the BMDP computer package (University of California) on the Amdahl computer at the University College, London, Computer Centre. A one-way analysis of variance (ANOVA) was carried out across the four groups using the program BMDP7D, which also performs pairwise Student's $t$ tests. When multiple groups were compared, the appropriate Bonferroni significance values were used to compensate for the number of groups, to reduce the probability of detecting spurious differences. Groups were only regarded as not showing significant differences, however, when the nominal probability of each significance test was greater than $0 \cdot 05 .^{16}$ Student's $t$ tests were also used in the program BMDP3D to compare the means for each variable in the combined groups, and to examine the effects of drug treatment within each group.

Stepwise discriminant analysis was carried out using the program BMDP7M with a 'jack knife' procedure to reduce any bias resulting from classifying a data set with a discriminant function produced from the same set.

\section{Results}

There were no significant differences between the four groups for age, duration of disease, number of patients receiving drug treatment, investigated by colonoscopy, or degree of disease activity. Variables for which the one way ANOVA was significant $(\mathrm{p}<0.05)$ are shown in Table II, with the Bonferroni significance values for the $t$ tests made between each pair of groups. There were no significant differences between biopsies from patients with total colitis and those with left sided colitis for any of the variables. Similarly there were no significant differences between distal colitis and proctitis. The other four pairs of comparisons showed two to five significant differences each. Five of the six differing variables were lamina propria cell counts, reflecting total cellularity (CELLEN), cell density (CARE), and cell densities at differ-

TABLE II Comparison of means for variables showing significant differences by Analysis of Variance (ANOVA)

\begin{tabular}{llllll}
\hline \multicolumn{5}{c}{ Student's ${ }^{\star}$} \\
\cline { 3 - 6 } Variable & ANOVA & \multicolumn{2}{c}{ Total colitis v: } & \multicolumn{2}{l}{ Left-sided colitis v: } \\
& Dist col & Proct & Dist Col & Proct \\
\hline CELLEN & $<0.001$ & $<0.001$ & $<0.005$ & $<0.05$ & NS \\
CARE & $<0.001$ & NS & $<0.005$ & $<0.05$ & $<0.005$ \\
HCDENS1 & $<0.001$ & NS & $<0.005$ & NS & $<0.005$ \\
HCDENS2 & $<0.005$ & NS & $<0.05$ & $<0.05$ & $<0.005$ \\
HCDENS3 & $<0.01$ & NS & $<0.05$ & NS & NS \\
MLA & $<0.005$ & $<0.005$ & NS & NS & NS \\
\hline
\end{tabular}

^Bonferroni significance levels; dist col $=$ distal proctocolitis; proct $=$ proctitis 
TABLE III Extensive and distal colitis and controls: (Derived) means and 95\% confidence limits for all variables

\begin{tabular}{|c|c|c|c|c|c|c|c|}
\hline \multirow{2}{*}{$\begin{array}{l}\text { Sample size } \\
\text { Variable }\end{array}$} & \multicolumn{2}{|l|}{$\begin{array}{l}\text { Controls } \\
23\end{array}$} & \multicolumn{2}{|c|}{$\begin{array}{l}\text { Extensive colitis } \\
17\end{array}$} & \multicolumn{2}{|l|}{$\begin{array}{l}\text { Distal colitis } \\
25\end{array}$} & \multirow{2}{*}{$\begin{array}{l}E C \vee D C \\
p\end{array}$} \\
\hline & Mean & $95 \% C L$ & Mean & $95 \% C L$ & Mean & $95 \% C L$ & \\
\hline IGM & 78 & $62-98$ & $181 \dagger$ & $85-387$ & $245 \ddagger$ & $166-360$ & \\
\hline IGG & 34 & $24-51$ & $336 \ddagger$ & $226-500$ & $455 \ddagger$ & $317-653$ & \\
\hline IGA & 250 & $219-286$ & $593 \ddagger$ & $431-816$ & $889 \neq$ & $721-1096$ & 0.024 \\
\hline SIE & 4 & $3-6$ & 5 & $2-11$ & $6+$ & 4-10 & \\
\hline CIE & 1 & $0-2$ & $18 \ddagger$ & $8-41$ & $46 \ddagger$ & $24-88$ & \\
\hline CLUM & 0 & $0-0$ & $1^{\star}$ & $0-2$ & $4 \ddagger$ & $1-8$ & \\
\hline LPP & 11 & 8-14 & $123 \ddagger$ & $73-208$ & $202 \ddagger$ & $135-304$ & \\
\hline CELLEN & 1368 & $1255-1490$ & $2710 \ddagger$ & $2195-3347$ & $4898 \ddagger$ & $4327-5544$ & $<0.001$ \\
\hline CARE & 5902 & $5140-6778$ & $8185 \ddagger$ & $7382-9074$ & $11350 \neq$ & $10310-12480$ & $<0.001$ \\
\hline HCDENS1 & 7727 & $6695-8915$ & 7568 & $6694-8557$ & $10910 \ddagger$ & $9736-12240$ & $<0.001$ \\
\hline HCDENS2 & 5370 & $4587-6287$ & $8531 \ddagger$ & $7658-9504$ & $11430 \ddagger$ & $10290-12690$ & $<0.001$ \\
\hline HCDENS3 & 4198 & $3656-4820$ & $8375 \ddagger$ & $7482-9376$ & $11300 \ddagger$ & $10080-12670$ & $<0.001$ \\
\hline HCDRAT & 1.87 & $1.73-2 \cdot 01$ & $\begin{array}{r}0.92 \ddagger \\
0.7\end{array}$ & $0.82-1.03$ & $1 \cdot 00 \ddagger$ & $0.98-1 \cdot 12$ & \\
\hline SLR & 1.05 & $1.04-1.06$ & $1 \cdot 17 t$ & $1 \cdot 09-1 \cdot 24$ & $1.09+$ & $1 \cdot 07-1 \cdot 12$ & \\
\hline MLA & 0.236 & $0 \cdot 211-0 \cdot 261$ & $0.331 \neq$ & $0.291-0.371$ & $0.447 \ddagger$ & $0.399-0.495$ & $;<0.001$ \\
\hline CAMM & 0.213 & $0 \cdot 186-0 \cdot 241$ & $0.230^{+}$ & $0.183-0.277$ & $0.244^{+}$ & $0.192-0.296$ & \\
\hline CRYPTS & 6.6 & $5 \cdot 8-7 \cdot 5$ & $4 \cdot 2 \ddagger$ & $3 \cdot 5-5 \cdot 1$ & $3.8 \ddagger$ & $3 \cdot 2-4 \cdot 4$ & \\
\hline CRYPTEQV & $10 \cdot 3$ & $9 \cdot 1-11 \cdot 6$ & 7.67 & $6.4-8.9$ & $7 \cdot 4 \ddagger$ & $6 \cdot 4-8 \cdot 5$ & \\
\hline CRYVOLl & 49 & $44-54$ & 42 & $37-47$ & $40 \ddagger$ & $36-45$ & \\
\hline CRYVOL2 & 61 & $57-65$ & $49+$ & $42-56$ & $36 \ddagger$ & $28-44$ & 0.014 \\
\hline CRYVOLT & 47 & $44-51$ & $40^{\frac{1}{2}}$ & $35-46$ & $34 \ddagger$ & $31-38$ & \\
\hline MHMEAN & 398 & $369-427$ & $526 t$ & $458-594$ & $598 \neq$ & $524-657$ & \\
\hline CLMEAN & 356 & $333-378$ & $452 \dagger$ & $389-515$ & $458+$ & $400-516$ & \\
\hline CDMEAN & 77 & $71-84$ & $96 t$ & $86-106$ & $91^{\star}$ & $81-100$ & \\
\hline SEWMEAN & 38 & $35-41$ & $27+$ & $21-32$ & $20 \ddagger$ & $17-24$ & 0.039 \\
\hline CEWMEAN & 24 & $22-25$ & 26 & $23-29$ & $23^{+}$ & $21-25$ & \\
\hline ICDMEAN & 32 & $28-38$ & $53 \ddagger$ & $45-63$ & $63 \ddagger$ & $53-75$ & \\
\hline MHCOEFF & 0.10 & $0.09-0.12$ & $0 \cdot 11$ & $0 \cdot 10-0 \cdot 13$ & $0 \cdot 10$ & $0 \cdot 07-0 \cdot 12$ & \\
\hline CLCOEFF & 0.12 & $0 \cdot 10-0 \cdot 14$ & $0 \cdot 16^{\star}$ & $0 \cdot 12-0 \cdot 19$ & $0 \cdot 14$ & $0 \cdot 12-0.17$ & \\
\hline CDCOEFF & 0.15 & $0.13-0.17$ & $0.28 \ddagger$ & $0.21-0.35$ & $0 \cdot 29 \ddagger$ & $0.22-0.36$ & \\
\hline SEWCOEFF & $0 \cdot 18$ & $0 \cdot 15-0.20$ & $0 \cdot 24^{\star}$ & $0 \cdot 19-0 \cdot 30$ & $0 \cdot 27 \ddagger$ & $0.24-0.30$ & \\
\hline CEWCOEFF & 0.22 & $0.20-0.24$ & $0.31 \ddagger$ & $0.27-0.35$ & $0.31 \ddagger$ & $0.27-0.36$ & \\
\hline ICDCOEFF & 0.87 & $0.76-0.98$ & $0.91^{+}$ & $0.83-0.99$ & $0.95^{+}$ & $0.85-1.05$ & \\
\hline MUCLRAT & $1 \cdot 12$ & $1 \cdot 09-1 \cdot 14$ & $1 \cdot 17$ & $1 \cdot 10-1 \cdot 24$ & $1 \cdot 32 \ddagger$ & $1 \cdot 22-1 \cdot 42$ & 0.027 \\
\hline SCEWRAT & 1.63 & $1 \cdot 49-1 \cdot 78$ & $1.07 \ddagger$ & $0.88-1 \cdot 26$ & $0.90 \ddagger$ & $0.77-1.02$ & \\
\hline
\end{tabular}

$p$ values for significance of difference of means from control group: ${ }^{\star}<0.05 ; \uparrow<0.01 ; \ddagger<0.001$.

ent levels in the lamina propria (HCDENS1,2,3) and the other (MLA) measures lamina propria volume and thus affects cell density. The consistent difference in cellularity indicated that the four groups could be combined into two: extensive ulcerative colitis which comprised patients

TABLE IVa Acute and chronic extensive colitis: (derived) means and 95\% confidence limits

\begin{tabular}{|c|c|c|c|c|c|}
\hline \multirow{2}{*}{$\begin{array}{l}\text { Sample size } \\
\text { Variable }\end{array}$} & \multicolumn{2}{|c|}{$\begin{array}{l}\text { Acute extensive colitis } \\
8\end{array}$} & \multicolumn{2}{|c|}{$\begin{array}{l}\text { Chronic extensive colitis } \\
9\end{array}$} & \multirow{2}{*}{$\begin{array}{l}\mathrm{t} \text { test: } \\
p\end{array}$} \\
\hline & Mean & $95 \% C L$ & Mean & $95 \% C L$ & \\
\hline IGM & $274 \ddagger$ & $155-485$ & 125 & $45-347$ & \\
\hline IGG & $386 \ddagger$ & $282-530$ & $296 \ddagger$ & $133-657$ & \\
\hline IGA & $724 \ddagger$ & $537-977$ & $496^{\star}$ & 273-901 & \\
\hline SIE & 6 & $1-19$ & 5 & $1-14$ & \\
\hline CIE & $15 \dagger$ & $3-63$ & $22 \ddagger$ & $6-72$ & \\
\hline CLUM & 1 & $0-3$ & 1 & $0-4$ & \\
\hline LPP & $135 \ddagger$ & $44-407$ & $114 \ddagger$ & $62-211$ & \\
\hline CELLEN & $3083 \ddagger$ & $2244-4229$ & $2410 \dagger$ & 1711-3394 & \\
\hline CARE & $8414 \dagger$ & $6907-10250$ & $7998^{\star}$ & 6944-9212 & \\
\hline HCDENS1 & 7261 & $5665-9307$ & 7870 & $6923-9212$ & \\
\hline HCDENS2 & $9099 \ddagger$ & $7597-10900$ & $8072 \dagger$ & $6893-9450$ & \\
\hline HCDENS3 & $8831 \neq$ & $7127-10940$ & $8017 \ddagger$ & $6885-9335$ & \\
\hline HCDRAT & $0.84 \ddagger$ & $0.69-1.00$ & $1 \cdot 00 \ddagger$ & $0.84-1 \cdot 15$ & \\
\hline SLR & $1 \cdot 18$ & $1 \cdot 04-1 \cdot 32$ & $1 \cdot 15$ & $1 \cdot 04-1 \cdot 27$ & \\
\hline MLA & $0.356 \ddagger$ & $0 \cdot 312-0 \cdot 400$ & 0.309 & $0.233-0.385$ & \\
\hline CAMM & $0 \cdot 285^{\star}$ & $0.204-0.366$ & $0 \cdot 182$ & $0.135-0.229$ & 0.015 \\
\hline CRYPTS & $4 \cdot 7^{\star}$ & $3 \cdot 6-5 \cdot 8$ & $3 \cdot 9 \ddagger$ & $2 \cdot 6-5 \cdot 3$ & \\
\hline CRYPTEQV & $9 \cdot 4$ & $7 \cdot 6-11 \cdot 2$ & $6 \cdot 0 \ddagger$ & $5 \cdot 0-7 \cdot 1$ & 0.001 \\
\hline CRYVOLI & 43 & $37-50$ & 41 & $32-49$ & \\
\hline CRYVOL2 & $52^{\star}$ & $41-63$ & $47 \dagger$ & $35-58$ & \\
\hline CRYVOLT & 43 & $34-52$ & $38 \dagger$ & $31-46$ & \\
\hline MHMEAN & $611 \ddagger$ & $554-668$ & 451 & $348-554$ & 0.007 \\
\hline CLMEAN & $539+$ & $451-626$ & 375 & $313-437$ & 0.002 \\
\hline CDMEAN & 87 & $73-100$ & $104 \ddagger$ & $88-121$ & \\
\hline SEWMEAN & $21 \ddagger$ & $15-28$ & $32^{\top}$ & $24-41$ & 0.022 \\
\hline CEWMEAN & $23^{4}$ & $20-26$ & $28^{\star}$ & $23-33$ & \\
\hline ICDMEAN & $46^{\star}$ & $36-60$ & $60 \ddagger$ & $48-76$ & \\
\hline MHCOEFF & $0 \cdot 10$ & $0.07-0.14$ & $0 \cdot 13$ & $0 \cdot 10-0 \cdot 15$ & \\
\hline CLCOEFF & $0 \cdot 13$ & $0.08-0.19$ & $0 \cdot 18 t$ & $0.13-0.22$ & \\
\hline CDCOEFF & $0 \cdot 27$ & $0 \cdot 13-0 \cdot 40$ & $0.29 \dagger$ & $0 \cdot 20-0.37$ & \\
\hline SEWCOEFF & $0 \cdot 26 \dagger$ & $0 \cdot 19-0.34$ & 0.23 & $0 \cdot 13-0.33$ & \\
\hline CEWCOEFF & $0.29 \dagger$ & $0.22-0.35$ & $0.33 t$ & $0.26-0.39$ & \\
\hline ICDCOEFF & 0.89 & $0.80-0.99$ & 0.93 & $0.78-1.07$ & \\
\hline MUCLRAT & $1 \cdot 15$ & $1 \cdot 04-1 \cdot 26$ & $1 \cdot 19$ & $1.07-1.31$ & \\
\hline SCEWRAT & $1.94 \ddagger$ & $0.64-1.24$ & $1 \cdot 18 \dagger$ & $0.90-1.46$ & \\
\hline
\end{tabular}

p values for significance of difference of means from control group: ${ }^{\star}<0.05 ; \dagger<0.01 ; \ddagger<0.001$. with total and left sided colitis, and distal proctocolitis which included proctitis and distal colitis. The variables for these groups are compared in Table III. There were no significant differences in age, duration, activity, or drug treatment between the two combined groups. None of the variables which differed significantly between the two groups were significantly affected by treatment.

Comparison of the acute and chronic phases of extensive ulcerative colitis and distal proctocolitis is shown in Table IV. In extensive disease (Table IVa) the measures of total cellularity (CELLEN, CARE, HCDENS1,2,3) remained similar between the acute and chronic phases, but there was a very significant one third decrease in the number of crypts (CRYPTS). Crypt length (CLMEAN), total crypt area (CAMM), and mucosal height (MHMEAN) were also reduced. Surface epithelial cell height (SEWMEAN) increased to normal in the chronic phase in many cases. In distal disease (Table IVb) the most significant differences between acute and chronic cases were increased cell densities at all levels in the lamina propria (CARE, HCDENS1,2,3), although the only specifically measured cell population to increase significantly was IgG plasma cells. There was a reduction in crypt numbers (CRYPTS) in the chronic phase similar to that in extensive disease and there was a significant increase in variability of crypt length (CLCOEFF) and crypt diameter (CDCOEFF). When the acute phases of each were compared (Table V), in distal disease the total lamina propria cellularity (CELLEN) and mucosal volume (MLA) were increased compared to extensive disease, but measures of cell density were not significantly different. In the 
TABLE IVb Acute and chronic distal colitis: (derived) means and 95\% confidence limits

\begin{tabular}{|c|c|c|c|c|c|}
\hline \multirow{2}{*}{$\begin{array}{l}\text { Sample size } \\
\text { Variable }\end{array}$} & \multicolumn{2}{|c|}{$\begin{array}{l}\text { Acute distal colitis } \\
9\end{array}$} & \multicolumn{2}{|c|}{$\begin{array}{l}\text { Chronic distal colitis } \\
16\end{array}$} & \multirow{2}{*}{$\begin{array}{l}\mathrm{t} \text { test: } \\
p\end{array}$} \\
\hline & Mean & $95 \% C L$ & Mean & $95 \% C L$ & \\
\hline IGM & $329 \ddagger$ & $202-537$ & $205 t$ & $116-362$ & \\
\hline IGG & $250 \ddagger$ & $133-471$ & $652 \ddagger$ & $443-958$ & 0.005 \\
\hline IGA & $989 \ddagger$ & $761-1283$ & $836 \ddagger$ & $609-1147$ & \\
\hline SIE & $9^{\star}$ & $4-18$ & 5 & $3-9$ & \\
\hline CIE & $43 \ddagger$ & $14-129$ & $48 \ddagger$ & $19-119$ & \\
\hline CLUM & $3^{\star}$ & $1-7$ & $4^{\star}$ & $1-14$ & \\
\hline LPP & $237 \ddagger$ & $114-491$ & $186 \ddagger$ & $106-322$ & \\
\hline CELLEN & $4539 \ddagger$ & $3651-5644$ & $5117 \ddagger$ & $4326-6050$ & \\
\hline CARE & $9462 \ddagger$ & $8213-10900$ & $12560 \neq$ & $11320-13930$ & 0.001 \\
\hline HCDENS1 & $9290^{\circ}$ & $7678-11240$ & $11970 \ddagger$ & $10420-13740$ & 0.022 \\
\hline HCDENS2 & $9354 \ddagger$ & $8164-10720$ & $12790 \ddagger$ & $11420-14330$ & 0.001 \\
\hline HCDENS3 & $9484 \ddagger$ & $7711-11660$ & $12500 \ddagger$ & $11000-14220$ & 0.012 \\
\hline HCDRAT & $1.02 \ddagger$ & $0.81-1.22$ & $1 \cdot 00 \ddagger$ & $0.84-1.15$ & \\
\hline SLR & $1 \cdot 08^{\star}$ & $10 \cdot 5-1 \cdot 11$ & $1 \cdot 10^{\star}$ & $1 \cdot 06-1 \cdot 14$ & \\
\hline MLA & $0.490 \ddagger$ & $0.414-0.566$ & $0.423 \ddagger$ & $0.357-0.489$ & \\
\hline CAMM & $0 \cdot 271^{\star}$ & $0.207-0.335$ & $0.229^{\circ}$ & $0 \cdot 152-0.306$ & \\
\hline CRYPTS & $4 \cdot 6 \dagger$ & $3 \cdot 4-6 \cdot 0$ & $3 \cdot 4 \ddagger$ & $2 \cdot 8-4 \cdot 1$ & 0.049 \\
\hline CRYPTEQV & $9 \cdot 2$ & $7 \cdot 4-11 \cdot 0$ & $6 \cdot 5 \ddagger$ & $5 \cdot 2-7 \cdot 8$ & 0.011 \\
\hline CRYVOLl & 41 & $32-50$ & $40^{\star}$ & $34-46$ & \\
\hline CRYVOL2 & $43^{\star}$ & $27-58$ & $32 \ddagger$ & $22-43$ & \\
\hline CRYVOLT & $36 \ddagger$ & $29-42$ & $34 \ddagger$ & $28-39$ & \\
\hline MHMEAN & $603 \ddagger$ & $546-659$ & $582 \dagger$ & $478-686$ & \\
\hline CLMEAN & $502 \dagger$ & $430-575$ & 432 & $348-517$ & \\
\hline CDMEAN & 79 & $68-90$ & $97 \dagger$ & $85-110$ & 0.043 \\
\hline SEWMEAN & $20 \ddagger$ & $15-26$ & $20 \ddagger$ & $16-26$ & \\
\hline CEWMEAN & 23 & $20-26$ & $24^{\circ}$ & $21-26$ & \\
\hline ICDMEAN & $51 \dagger$ & $38-70$ & $72 \ddagger$ & $58-88$ & $0 \cdot 049$ \\
\hline MHCOEFF & $0 \cdot 07^{\star}$ & $0 \cdot 04-0 \cdot 11$ & $0 \cdot 11$ & $0.08-0.14$ & \\
\hline CLCOEFF & $0 \cdot 09^{\star}$ & $0 \cdot 07-0 \cdot 10$ & $0 \cdot 17 \dagger$ & $0 \cdot 14-0 \cdot 21$ & $<0.001$ \\
\hline CDCOEFF & $0 \cdot 21$ & $0.14-0.27$ & $0 \cdot 34 \ddagger$ & $0.24-0.43$ & 0.047 \\
\hline SEWCOEFF & $0 \cdot 30 \ddagger$ & $0.25-0.36$ & $0.25 t$ & $0.21-0.29$ & \\
\hline CEWCOEFF & $0 \cdot 32^{\star}$ & $0 \cdot 22-0 \cdot 41$ & $0.31 \dagger$ & $0.26-0.36$ & \\
\hline ICDCOEFF & 0.97 & $0 \cdot 73-1 \cdot 21$ & 0.94 & $0.82-1.06$ & \\
\hline MUCLRAT & $1 \cdot 22$ & $1 \cdot 07-1 \cdot 37$ & $1 \cdot 38 \ddagger$ & $1 \cdot 24-1 \cdot 51$ & \\
\hline SCEWRAT & $0.92 \ddagger$ & $0 \cdot 73-1 \cdot 11$ & $0.88 \ddagger$ & $0 \cdot 70-1.07$ & \\
\hline
\end{tabular}

p values for significance of difference of means from control group: ${ }^{\star}<0.05 ; \dagger<0.01 ; \ddagger<0.001$.

chronic phase there were highly significant increases in cell density at all levels (CARE, HCDENS1,2,3) as well as total cellularity (CELLEN) in distal proctocolitis compared with extensive ulcerative colitis.

Discriminant analysis and jack knife testing achieved $93 \%$ separation of distal proctocolitis from extensive ulcerative colitis, using four variables which measured cell density and distribution of cells in the lamina propria, and mucosal volume: CELLEN, HCDRAT, MLA, and HCDENS3. Overall lamina propria cell density (CARE) and a measure of surface irregularity (SLR) could be substituted for the measures of cell density in the basal third of the lamina propria (HCDENS3) and of mucosal volume (MLA) respectively with $88 \%$ discrimination. For the acute cases only complete discrimination was achieved using mucosal volume (MLA), IgG plasma cell count (IGG), and numbers of crypt profiles (CRYPTEQV), while for the chronic cases only, cell density in the lamina propria (CARE) and mucosal volume (MLA), gave $92 \%$ discrimination.

TABLE V Extensive colitis v distal colitis: variables for which the difference of means is significant

\begin{tabular}{llr}
\hline & \multicolumn{2}{l}{$\begin{array}{l}\text { pvalues for t tests } \\
\text { between: }\end{array}$} \\
\cline { 2 - 3 } Variable & $\begin{array}{l}\text { Acute } \\
\text { cases }\end{array}$ & $\begin{array}{l}\text { Chronic } \\
\text { cases }\end{array}$ \\
\hline IGG & NS & 0.034 \\
CELLEN & 0.026 & $<0.001$ \\
CARE & NS & $<0.001$ \\
HCDENS1 & NS & $<0.001$ \\
HCDENS2 & NS & $<0.001$ \\
HCDENS3 & NS & $<0.001$ \\
MLA & 0.003 & 0.026 \\
SEWMEAN & NS & 0.009
\end{tabular}
all ulcerative colitis as an identical process differing only in extent. It appears appropriate to group proctitis and distal colitis as 'distal proctocolitis', and to distinguish this from 'extensive ulcerative colitis'. The mean total lamina propria cellularity, measured per millimetre of mucosal length, in distal proctocolitis approaches twice that of extensive colitis. This highly significant increase cannot be explained by differences in age, duration, activity, or drug usage, and the difference is still present when only untreated cases are compared.

In acute distal proctocolitis there is excess total cellularity with a high lamina propria volume, and cell density is not increased. In the chronic active cases the cell density and total cell numbers are increased compared with the acute cases. This contrasts with the chronic, but still active, phase of extensive colitis. The surface epithelial height parallels the inflammatory infiltrate and is reduced in both groups in the acute phase; in the chronic phase it returns to normal in extensive disease but remains low in distal proctocolitis. Very little of the difference in cellularity can be explained by any changes in the measured specific cell populations. The only significant difference was in IgG plasma cells in chronic disease. Eosinophils and IgE plasma cells were not counted in this study, but none of the cases showed the heavy eosinophilia described for allergic proctitis in children under two years old, ${ }^{11}$ and in a previous study no difference was found in IgE plasma cell counts between proctitis and other ulcerative colitis. ${ }^{13}$ It therefore appears that the major difference is in the number of lymphocytes, histiocytes, or other mononuclear cells in the lamina propria.

Further studies are needed to establish whether the increased lamina propria cell infiltration found in distal proctocolitis represents a quantitative or a qualitative difference from more widespread colitis. The similarity of the crypt damage suggests that the two might be related diseases, differing in intensity or pattern of immune response. The failure of conventional histology to detect the differences in cell populations is not surprising as subjective judgment of cellularity is not highly reproducible.

The differences identified do not conflict with the observation that there is variation in extent of ulcerative colitis with time. Most of the variation in extent is confined to the distal colon and rectum, with the cumulative probability of extension of proctitis to the sigmoid colon at 20 years approximately $29 \%$ (SD of $6 \%$ ) using a combination of rigid sigmoidoscopy and barium enema. ${ }^{7}$ Colonoscopic study has suggested that the rate of this extension may be up to $45 \%$. $^{+}$The rate of extension of localised proctosigmoiditis to involve the proximal colon is much lower, about $10-15 \%$ in the same studies. Extensive ulcerative colitis also appears to vary in extent at different times. ${ }^{+}$The cases studied here were assessed by both colonoscopy and double contrast barium enema, but there is no evidence of any systematic bias which could have affected the demonstration of a relationship between quantitative histological changes and extent.

The variation in extent could be accounted for by the existence of two disease processes, distal proctocolitis variably involving the rectum and sigmoid with time, and more extensive ulcerative colitis which could sometimes present as a proctitis and may also regress to involve only the rectum during remission. The low rate of progression of distal proctocolitis to extensive disease and the finding that over $90 \%$ of distal proctocolitis can be identified as a histological entity by discrimant analysis support this. The correct prediction of subsequent progression of 
one patient in this study, who presented with rectal disease, to extensive ulcerative colitis provides some support for this hypothesis. It may be possible to quantitatively predict those cases of distal proctocolitis at risk of progression to extensive disease.

Other differences support a two disease hypothesis. The difficulty of inducing complete remission is consistent with the finding that cell counts increase with transition of distal proctocolitis to a chronic phase. ${ }^{1819}$ The similar duration of disease before presentation and similar age at presentation for patients with limited disease and those with total colitis, suggests that these, in general, are not sequential processes..$^{20}$ In proctitis the risk of systemic complications is low and associated with progression and few patients require surgery. ${ }^{189}$ Many patients may not have recurrent disease after a single attack, even with long follow up. ${ }^{\prime}$ There is also a low risk of developing carcinoma compared with extensive ulcerative colitis. ${ }^{3 \times}$

Recognition of two different patterns in pathological process related to extent of disease may resolve some of the confusion and uncertainty, clinical and scientific, over inflammatory bowel disease.

We thank Mr Brian Thornton for technical assistance; Dr David Spiegelhalter for statistical advice; and the National Association for Colitis and Crohn's Disease for financial support.

1 Ritchie JK, Hawley PR. Idiopathic proctitis. In: Allan RN, Keighley MRB, Alexander-Williams J, Hawkins C, eds. Inflammatory bowel diseases. Edinburgh: Churchill LivingInflammatory bowel
stone, 1983: 101-6.

2 Farmer RG, Brown CH. Emerging Concepts of Proctosigmoiditis. Dis Colon Rectum 1972; 15: 142-6.

3 Farmer RG. Long-term prognosis for patients with ulcerative proctosigmoiditis (ulcerative colitis confined to the rectum and sigmoid colon). $\mathcal{F}$ Clin Gastroenterol 1979; 8: 47-50.
4 Niv Y, Bat L, Ron E, Theodor E. Change in the extent of colonic involvement in ulcerative colitis: a colonoscopic study. Am f Gastroenterol 1987; 10: 1046-51.

5 Gabrielsson N, Granqvist S, Sundelin P, Thorgeirsson T Extent of inflammatory lesions in ulcerative colitis assessed by radiology, colonoscopy, and endoscopic biopsies. Gastrontest Radiol 1979; 4: 395-400.

6 Lennard-Jones JE, Cooper GW, Newell AC, Wilson CWE, Avery Jones F. Observations on idiopathic proctitis. Gut 1962; 3: 201-6.

7 Powell-Tuck J, Ritchie JK, Lennard-Jones JE. The Prognosis of idiopathic proctitis. Scand $\mathcal{F}$ Gastroenterol 1977; 12: 72732.

8 Ritchie JK, Powell-Tuck J, Lennard-Jones JE. Clinical outcome of the first ten years of ulcerative colitis and proctitis Lancet 1978; i: 1140-3.

9 Myers A, Humphreys DM, Cox EV. A ten-year follow-up of haemorrhagic proctitis. Postgrad Med f 1976; 52: 224-8

10 Flejou JF, Potet F, Bogomoletz WV, et al. Lymphoid follicular proctitis. A condition different from ulcerative proctitis? Dig Dis $S_{c i}$ 1988; 33: 314-20.

11 Goldman H, Proujansky R. Allergic proctitis and gastroenteritis in children. Clinical and mucosal biopsy features in enteritis in children. Clinical and mucosal b
53 cases. Am 7 Surg Pathol 1986; 10: 75-86.

12 Rosekrans PC, Mejer CJ, Van der Was AM, Lindeman J. Allergic proctitis: a clinical and immunopathological entity Gut 1980; 21: 1012-23.

13 Scott BB, Goodall A, Stephenson P, Jenkins D. Rectal mucosal plasma cells in inflammatory bowel disease. Gu $1983 ; 24: 519-24$

14 Jenkins D, Goodall A, Drew K, Scott BB. What is colitis? A statistical approach to distinguishing clinically importan inflammatory changes in rectal biopsy specimens. 7 Clin Pathol 1988; 41: 72-9.

15 Scott BB, Goodall A, Drew K, Jenkins D. Predicting infective colitis: a quantitative and statistical approach to the diagnosis of acute colitis on rectal biopsy [Abstract]. Gut 1988; 29: A1473.

16 Godfrey K. Comparing the means of several groups. $N E n g$ F Med 1985; 313: 1450-6.

17 Allison MC, Hamilton-Dutoit SJ, Dhillon AP, Pounder RE. The value of rectal biopsy in distinguishing self-limited colitis from early inflammatory bowel disease. $Q \mathcal{F} \mathrm{Med}$ 1987; 65: 985-95.

18 Friedman LS, Richter JM, Kirkham SE, DeMonaco HJ, May RJ. 5-aminosalicylic acid enemas in refractory distal ulcerative colitis: a randomized controlled trial. Am $\mathcal{F}$ Gastroenterol 1986; 81: 412-8.

19 Barber GB, Lee DE, Antonioli DA, Peppercorn MA. Refractory distal ulcerative colitis responsive to 5 Refractory distal ulcerative colitis responsive to 5
aminosalicylate enemas. Am $\mathcal{F}$ Gastroenterol $1985 ; 80: 612-4$

20 Holdstock G, DuBoulay CE, Smith CL. Survey of the use of colonoscopy in inflammatory bowel disease. Dig Dis $\mathrm{Sci}$ 1984; 29: 731-4. 